\title{
The relationship between corporate governance attributes and environmental disclosure quality of Malaysian public listed companies
}

\begin{abstract}
This study aims to assess the effects of corporate governance attributes consists of proportion of independent directors, non-duality of Chief Executive Officer (CEO), board size and managerial ownership on environmental disclosure quality of Malaysian public listed companies. Besides good financial returns, companies today are also expected by its stakeholders to contribute back to the society in terms of sustainability activities despite Malaysia is still in the midst of improving the corporate governance. The composition of corporate board assistances in improving corporate performance remains as an issue. Environmental improvement and contribution commonly made through environmental disclosure, however, besides complying with regulations and being voluntary in reporting on environmental, the quality of the environmental disclosure is still unclear. This study is carried out in Malaysia among companies in environmentally sensitive industry as the operations of environmentally sensitive industry are considered to be more detrimental to the environment. Data are extracted from companies' annual reports over five years' duration, namely year 2012 to 2016 . The data collected is being analyzed using panel data analysis. The proportion of independent directors and non-duality of CEO are significant in improving the environmental disclosure quality of Malaysian listed companies.
\end{abstract}

Keyword : Independent directors; Non-duality of CEO; Board size and managerial ownership; Environmental disclosure quality; Environmentally sensitive industry 